J. Pijar MIPA, Vol. V No.2, September : 71 - 75

ISSN 1907-1744

\title{
PEMBELAJARAN QUANTUM MODEL TANDUR UNTUK MEMBANGUN KOMUNIKASI EFEKTIF DALAM PEMBELAJARAN
}

\author{
Baiq Sri Handayani \\ Program Studi Pendidikan Biologi PMIPA FKIP Universitas Mataram \\ Jl. Majapahit No. 62 Mataram 83125
}

\begin{abstract}
Abstrak : Kualitas pembelajaran dipengaruhi oleh efektif tidaknya komunikasi yang terjadi di dalamnya. Komunikasi efektif dalam pembelajaran merupakan proses transformasi pesan berupa ilmu pengetahuan dan teknologi dari pendidik kepada peserta didik, dimana peserta didik mampu memahami maksud pesan sesuai dengan tujuan yang telah ditentukan, sehingga menambah wawasan ilmu pengetahuan dan teknologi serta menimbulkan perubahan tingkah laku menjadi lebih baik. Pengajar adalah pihak yang paling bertanggungjawab terhadap berlangsungnya komunikasi yang efektif dalam pembelajaran. Motode Pembelajaran Quantum Model Tandur merupakan salah satu media efektif dan bisa dipakai pengajar untuk membangun komunikasi efktif. Hal ini dilihat dari prinsip-prinsip Pembelajaran Quantum dan langkah-langkah pelaksanaannya Pembelajaran Quantum Model TANDUR.
\end{abstract}

Kata Kunci : Komunikasi fektif, Quantum Teaching, Model Tandur

\section{PENDAHULUAN}

Paradigma pembelajaran abad 21 menitikbertkan pada usaha guru dalam menhoptimalisasi potensi siswa untuk membangun pengetahuan. Guru merupakan ujung tombak berlangsunganya kegiatan pembelajaran karena kemapuan guru akan menghasilkan pembentukan kualitas peserta didiknya. Peserta didik harus aktif dalam pencarian dan pengembangan pengetahuan. Kebenaran ilmu tidak terbatas pada apa yang disampaikan oleh guru dan dosen. Guru dan dosen harus mengubah perannya, tidak lagi sebagai pemegang otoritas tertinggi keilmuan dan indoktriner, tetapi menjadi fasilitator yang membimbing peserta didik ke arah pembentukan pengetahuan oleh diri mereka sendiri. Diharapkan dalam pembelajaran di kelas siswa aktif dalam belajar, aktif berdiskusi, berani menyampaikan gagasan dan menghargai gagasan orang lain, serta memiliki kepercayaan diri yang tinggi .

Kegiatan pembelajaran merupakan proses transformasi pesan edukatif berupa materi belajar dari sumber belajar kepada pembelajar. Dalam pembelajaran terjadi proses komunikasi untuk menyampaikan pesan dari pendidik kepada peserta didik dengan tujuan agar pesan dapat diterima dengan baik dan berpengaruh terhadap pemahaman serta perubahan tingkah laku. Dengan demikian keberhasilan kegiatan pembelajaran sangat tergantung kepada efektifitas proses komunikasi yang terjadi dalam pembelajaran tersebut [10]

Agar tercapainya komunikasi yang efektif dalam pembelajaran sangat tergantung dari metode pembelajaran yang dipakai oleh guru dan dosen dalam pembelajaran. Metode pembelajaran merupakan salah satu faktor penting dalam membangun komunikasi yang efektif antara pendidik dan peserta didik. Salah satu metode yang dimaksud adalah Pembelajaran Quantum Model Tandur. Metode tersebut sangat memungkinkan untuk membangun komunikasi efektif antara pengajar dan peserta didik.

\section{PEMBAHASAN}

\subsection{Komunikasi Yang Efektif}

Komunikasi adalah proses penyampaian pesan oleh komunikator kepada komunikan melalui media yang menimbulkan efek tertentu [8]. Komunikasi adalah suatu proses, bukan sesuatu yang bersifat statis. Komunikasi memerlukan tempat, dinamis, menghasilkan perubahan dalam usaha mencapai hasil, melibatkan interaksi bersama, serta melibatkan suatu kelompok [10]

Komunikasi merupakan salah satu kompetensi penting yang harus dikuasi oleh guru atau pengajar. Tekhnik penyampain informasi dan bantahan dengan cara yang baik dalam pembelajaran akan memberikan dampak yang baik terhadap keberhasilan pembelajaran. Perihal komunikasi Allah SWT telah berfirman dalam alquran Surat Annahal QS 16:124

"Serulah (manusia) kepada jalan Tuhanmu dengan hikmah dan pelajaran yang baik dan bantahlah mereka dengan cara yang baik. Sesungguhnya Tuhanmu Dialah yang lebih mengetahui tentang siapa yang tersesat dari jalan-Nya dan Dialah yang lebih mengetahui orang-orang yang mendapat petunjuk."

Dalam ayat tersebut manusia diperintahkan untuk menyapaikan sesuatu yang baik kepada orang lain dengan cara yang baik. Dalam pembelajaran cara yang baik mengandung makna luas mulai dari tehnik penyampaian, disain lingkungan kelas dan pengelolaan kelas samapai kepada sekenario pembelajaran yang dirancang guru. Namun dalam realitanya sering kali terjadi apa yang disampiakan oleh pembawa pesan (komonikator) dalam hal ini guru terkadang tidak dapat diterima sepenuhnya oleh penerima pesan (komunikan/peserta didik) sehingga terjadi kesalah pahaman (miskomunikasi) antara pendidik dan peserta didik. Dalam pembelajaran kesalahpahaman penerimaan konsep disebabakan oleh banyak faktor diantaranya tidak tepatnya metode yang dipakai, guru kurang menguasai konsep, atau tidak kondusifnya lingkungan kelas untuk belajar.

Hal-hal penting yang perlu diperhatikan saat proses informasi untuk komunikasi dalam pembelajaran, antara lain: (1) hal yang akan disampaikan kepada penerima tanpa ada pembiasan isi (subject $=$ outcome), (2) hal yang akan disampaikan sesuai dengan kemampuan siswa dalam menelaah (tingkat intelegensi siswa, pengalaman-pengalaman yang pernah didapat), (3) siswa terikat secara aktif dalam proses belajar dengan cara menghubungkan apa yang mereka dapat sebelumnya dengan hal baru yang akan disampaikan, (4) siswa diminta menunjukkan kemajuan sehingga pencapaiannya dapat dianalisis, umpan balik mendapat respon sehingga terlihat jelas sukses dalam usahanya, dan (5) siswa diberi waktu 
luang yang cukup untuk berlatih dengan kondisi beragam untuk meyakinkan proses retensi dan tranfer yang sedang terjadi [8].

Komunikasi dan interaksi dalam pembelajaran memiliki peran sentral dalam perkembangan intelektual, sosial, dan emosional peserta didik dan merupakan penunjang keberhasilan dalam mempelajari semua bidang studi. Model pembelajaran yang patut dipertimbangkan adalah model pembelajaran yang lebih banyak mendorong terjadinya interaksi dan komunikasi peserta didik, dengan adanya interaksi dan komunikasi akan dapat memotivasi peserta didik menguasai materi pelajaran [5]

\subsection{Pembelajaran Quantum (Quantum teaching)}

Pembelajaran quantum berfokus pada hubungan dinamis dalam lingkungan kelas-interaksi yang mendirikan landasan dan kerangka untuk belajar. Quantum teaching mencakup petunjuk spesifik untuk menciptakan lingkungan belajar yang efektif merancang kurikulum, menyampaikan isi dan memudahkan proses belajar. Asas Utama Model Pembelajaran Quantun bersandar pada konsep; "bawalah dunia mereka ke dunia kita dan antarkan dunia kita ke dunia mereka" [4]

Asas utama Quantum Teaching menurut pendapat Bobbi DePorter dalam [3] adalah semua aspek kepribadian manusia. Semua aspek itu meliputi pikiran, perasaan, bahasa isyarat, pengetahuan, sikap dan keyakinan serta persepsi masa mendatang. Jadi proses belajar akan berhasil apabila dengan cara mengaitkan materi yang diajarkan dengan suatu peristiwa, pikiran atau perasan yang diperoleh dari kehidupan rumah. Belajar akan berhasil bila guru bisa memahami keadaan siswa, sehingga semua materi atau pesan yang disampaikan akan tertanam di hati siswa tersebut. Akhirnya dengan pengertian yang lebih luas dan penguasaan lebih mendalam, siswa dapat mengambil apa yang mereka pelajari ke dalam dunia mereka dan menerapkannya pada situasi baru.

Kata Quantum sendiri berarti interaksi yang mengubah energi menjadi cahaya. Jadi Quantum Teaching menciptakan lingkungan belajar yang efektif, dengan cara menggunakan unsur yang ada pada siswa dan lingkungan belajarnya melalui interaksi yang terjadi di dalam kelas. Persamaan Quantum Teaching ini diibaratkan mengikuti konsep Fisika Quantum yaitu:

$$
\mathbf{E}=\mathbf{m} c^{2}
$$

$\mathrm{E}=$ Energi (antusiasme, efektivitas belajarmengajar,semangat)

$\mathrm{m}=$ massa (semua individu yang terlibat, situasi, materi, fisik)

$c=$ interaksi (hubungan yang tercipta di kelas)

Berdasarkan persamaan tersebut dapat dipahami, interaksi serta proses pembelajaran yang tercipta akan berpengaruh besar sekali terhadap efektivitas dan antusiasme belajar peserta didik. Bila metode ini diterapkan, maka guru akan lebih berhasil dalam memberikan materi serta lebih dicintai anak didik karena guru mengoptimalkan berbagai metode [12].

Quantum Teaching adalah orkestra dari warnawarni interaksi yang ada di dalam dan disekitar momen belajar. Interaksi-interaksi ini mencakup unsur-unsur belajar efektif yang mempengaruhi kesuksesan siswa. Interaksi-interaksi ini mengubah kemampuan dan bakat alamiah siswa menjadi cahaya yang akan bermanfaat bagi dirinya dan orang sekitarnya. Orkestra merupakan kolaborasi berbagai interaksi belajar yang terdiri dari konteks maupun kontens. Konteksnya meliputi (1) suasana pembelajaran, (2) landasan/kerangka kerja (3) lingkungan pembelajaran (4) perancangan pembelajaran yang dinamis. Sedangkan kontensnya meliputi (1) presentasi/cara penyampaian materi (2) pemberdayaan fasilitas (3) ketrampilan hidup [12].

Menurut Bratasari R [1] dengan Quantum teaching guru dapat mengajar dengan memfungsikan kedua belahan otak kiri dan otak kanan pada fungsinya masing-masing. Penelitian di Universitas California mengungkapkan bahwa masing-masing otak tersebut mengendalikan aktivitas intelektual yang berbeda. Otak kiri menangani angka, susunan, logika, organisasi, dan hal lain yang memerlukan pemikiran rasional, beralasan dengan pertimbangan yang deduktif dan analitis. Bagian otak ini yang digunakan berpikir mengenai hal-hal yang bersifat matematis dan ilmiah. Kita dapat memfokuskan diri pada garis dan rumus, dengan mengabaikan kepelikan tentang warna dan irama. Otak kanan mengurusi masalah pemikiran yang abstrak dengan penuh imajinasi. Misalnya warna, ritme, musik, dan proses pemikiran lain yang memerlukan kreativitas, orisinalitas, daya cipta dan bakat artistik. Pemikiran otak kanan lebih santai, kurang terikat oleh parameter ilmiah dan matematis. Kita dapat melibatkan diri dengan segala rupa dan bentuk, warnawarni dan kelembutan, dan mengabaikan segala ukuran dan dimensi yang mengikat.

Jika guru dengan metode yang digunakan mampu menfungsikan kedua otak yaitu otak kiri dan kanan maka proses belajar mengajar akan lebih efektif. Ketika otak kiri mulai bosan dengan hal-hal yang bersifat matematis dan ilmiah maka siswa akan sulit menerima pelajaran sehingga perlu diseimbangkan dengan kegiatan-kegiatan otak kanan yang lebih santai. Apabila dalam pembelajaran siswa merasa santai, nyaman dan rileks maka komunikasi antara siswa dan siswa atau siswa dengan guru akan berlangsung efektif. Untuk mendapatkan kondisi santai, nyaman dan rileks maka guru perlu merancang lingkungan kelas yang dinamis.

Dengan demikian pembelajaran dapat dimaknai sebagai interaksi antara pendidik dengan peserta didik yang dilakukan secara sengaja dan terencana serta memiliki tujuan yang positif. Keberhasilan pembelajaran harus didukung oleh komponen-komponen instuksional yang terdiri dari pesan berupa materi belajar, penyampai pesan yaitu pengajar, bahan untuk menuangkan pesan, peralatan yang mendukung kegiatan belajar, teknik atau metode yang sesuai, serta latar atau situasi yang kondusif bagi proses pembelajaran [10].

\subsubsection{Prinsip-prinsip Quantum Teaching}

Menurut Dobbi DePorter dalam Cahyono NA [3] Prinsip-prinsip Quantum Teaching meliputi:

1) Segalanya berbicara : Segalanya dari lingkungan kelas hingga bahasa tubuh, bahasa isyarat mereka, semuanya mengirim pesan untuk belajar, 2) Segalanya 
mempunyai tujuan: Semua yang dilakukan guru mempunyai tujuan, 3) Pengalaman sebelum pemberian nama: Otak bisa berkembang pesat dengan adanya rangsangan komunikasi yang akan menggerakkan rasa ingin tahu, oleh karena itu proses belajar paling baik terjadi ketika siswa telah mendapat informasi sebelum mereka memperoleh nama untuk mempermudah mereka mempelajari, 4) Semua usaha siswa harus diakui: Belajar mempunyai aturan, belajar berarti melangkah keluar dari kenyataan. Pada saat siswa mengambil langkah ini, mereka pantas mendapat pengakuan atas kecakapan dan kepercayaan diri mereka sehingga merasa bangga dengan kemampuan yang mereka miliki bisa menimbulkan minat yang lebih besar, 5) Jika pantas dipelajari maka pantas dirayakan: Guru sebaiknya sering memberi hadiah kepada siswa yang berhasil dalam menyelesaikan tugas dengan cepat dan benar. Dengan pemberian hadiah berupa pujian, mereka akan merasa dihargai, sehingga mereka akan selalu berusaha agar dapat memecahkan masalah tugas yang diberikan.

\subsubsection{Konsep TANDUR Sebagai Model Pembelajaran}

Dalam pembelajaran apabila antara pendekatan, strategi, metode, teknik dan bahkan taktik pembelajaran sudah terangkai menjadi satu kesatuan yang utuh maka terbentuklah apa yang disebut dengan model pembelajaran. Model pembelajaran merupakan bentuk pembelajaran yang tergambar dari awal sampai akhir yang disajikan secara khas oleh guru. Atau dengan kata lain, model pembelajaran merupakan bungkus atau bingkai dari penerapan suatu pendekatan, metode, dan teknik pembelaajaran [11]

Setiap model pembelajaran memiliki sintaks atau langkah-langkah yang akan diterapkan dalam pembelajaran. Sintaks. Langkah pelaksanan model pembelajaran TANDUR sebagai berikut:

$\mathbf{T}=$ Tumbuhkan, menumbuhkan minat belajar siswa yaitu menjalin interaksi dengan siswa dan menyakinkan mereka mengapa harus mempelajari materi ini. Menurut Uzer Usman dalam Cahyono [2] untuk menumbuhkan minat dan perhatian siswa dapat dilakukan,

a. Menyampaikan tujuan pembelajaran.

b. Menyampaikan aplikasi dan kegunaan dari bahan yang akan dipelajari, siswa memahami manfaat materi.

c. Mengaitkan materi yang akan diajarkaan dengan apa yang telah diketahui siswa.

d. Mengadakan kompetisi antar siswa, misal dengan membagi kelompok, tiap kelompok diberi tugas kemudian mempresentasikannya.

e. Menggunakan media yang relevan

f. Menciptakan lingkungan fisik, emosional dan sosial yang kondusif, misalnya cara penyusunan kursi, menciptakan kondisi yang harmonis antara siswa.

A =Alami : Konsep-konsep yang abstrak disajikan menjadi nyata, maka guru perlu membuat siswa mengalami langsung hal-hal yang dipelajari. Untuk melaksanakan langkah ini guru memanfaatkan internet. $\mathbf{N}=$ Namai: ketika minat dan perhatian telah tumbuh dan berbagai pertanyaan muncul dalam pikiran siswa, maka pada saat itu guru memberi informasi atau konsep yang diinginkan, di sini disebut dengan langkah penamaan. Dengan langkah penamaan ini diharapkan akan menjawab tuntas keraguan dan berbagai pertanyaan ketika masih pada tahap mengalami.

D = Demontrasikan: Pada saat siswa belajar sesuatu yang baru dan mereka diberi pengalaman dan ditunjukkan konsep yang benar (Penamaan) dan diberi kesempatan untuk berbuat (Demontrasi). Setelah sisiwa mengalami belajar akan sesuatu, berarti kesempatan kepada mereka untuk mendemonstrasikan kemampuannya,. Melalui pengalaman belajar tersebut siswa akan mengerti dan mengetahui bahwa dia memiliki kemampuan dan informasi yang cukup.

$\mathbf{U}=$ Ulangi: memperoleh pengetahuan hanya dengan jalan mengalami satu kali saja atau diingat setengah-setengah jelas akan mudah sekali terlupakan dan bahkan tidak akan menetap dalam ingatan siswa, sebaliknya pengetahuan dan pengalaman yang sering diulang-ulang akan menjadi pengetahuan yang tetap dan dapat digunakan kapan saja. $\mathbf{R}=$ Rayakan, Ekspresi kelompok yang telah berhasil, misalnya dengan bertepuk tangan atau bernyanyi [2]

\subsection{Menciptakan Lingkungan yang Mendukung}

Lingkungan adalah segala sesuatu yang ada di luar diri individu. Adapun lingkungan pengajaran merupakan segala apa yang bisa mendukung pengajaran itu sendiri yang dapat difungsikan sebagai "sumber pengajaran" atau "sumber belajar". Bukan hanya guru dan buku/bahan pelajaran yang menjadi sumber belajar. Tetapi banyak hal yang dapat dipelajari dan dijadikan sumber belajar peserta didik dari lingkungan. Pengajaran yang tidak menghiraukan prinsip lingkungan akan mengakibatkan peserta didik tidak akan mampu beradaptasi dengan kehidupan tempat ia hidup. Pengetahuan yang mungkin ia kuasai belum menjamin pada bagiman ia menerapkan pengetahuannya itu bagi lingkungan yang ia hadapi [9]. Lingkungan pembelajaran perlu dikelola agar kondusif. Lingkungan ini tidak terbatas hanya pada lingkungan fisik, tetapi juga lingkungan non fisik. Tentunya tidak dikehendaki lingkungan belajar yang tidak terkonrol, tetapi juga tidak sepi mencekam.

Tugas guru yang tidak kalah penting adalah bagaimana menyiapkan lingkungan belajar sehingga proses belajar terkesan "belajar itu hidup, segar, penuh semangat", atau "datang dan jelajahilah". Segala bentuk penataan lingkungan mempunyai maksud tertentu mulai dari cara poster ditempelkan di dinding, pengaturan bangku, penyusunan bahan pembelajaran, hingga tingkat kebersihan kelas semuanya berbicara. Karena lingkungan kelas yang tertata baik akan mendukung sistem kognitif siswa dalam pembelajaran.

Sistem pembelajaran kognitif otak paling banyak menerima perhatian karena sistem ini berhubungan dengan membaca, menulis, berhitung, dan semua aspek lain dalam pengembangan kecakapan akademis. Dewasa ini standar pembelajaran siswa berfokus pada hasil sistem pembelajaran kognitif. Namun tanpa perhatian terhadap sistem-sistem lainnya, siswa tidak mampu meraih potensi maksimal mereka. Sistem pembelajaran kognitif berkembang jika informasi baru diberikan dalam bentuk satuan pembelajaran bertema yang mengkaitkan seni, musik, dan kegiatan fisik dengan dunia nyata siswa [6]. 
Menurut DePorter dalam Mahmuddin [7] guru tidak dapat mengajar lebih banyak dengan usaha lebih sedikit. Akan tetapi, guru dapat menyampaikan isi lebih banyak dan siswa mengerti lebih banyak. Hal itu dapat dicapai dengan mengubah lingkungan. Belajar terjadi baik secara sadar maupun tidak sadar dalam waktu bersamaan. Otak senantiasa dibanjiri stimulus, dan otak memilih fokus tertentu saat demi saat. Misalnya, ketika sebuah gambar ditampilkan baik dalam proses belajar maupun berupa pajangan kelas, maka di samping proses hal itu merangsang modalitas belajar visual, juga dapat menimbulkan asosiasi dalam kesadaran melalui jalur saraf. Sehingga lingkungan sekeliling dapat dimanfaatkan untuk meningkatkan kemampuan siswa secara tidak sadar menyerap informasi melalui kemitraan otak-mata.

Dalam pengelolaan lingkungan pembelajaran quantum bebrapa hal yang perlu diperhatikan diantaranya: 1). Pemajangan poster-poster ikon di kelas; Dalam pembelajaran quantum hendaknya menjadi perhatian guru karena akan membantu penciptaan, penyimpanan, dan pencarian informasi secara visual. Untuk efektivitasnya, pemasangan pajangan harus dikelola pada setiap sisi kelas dengan mengatur tata letak antar pajangan untuk materi yang sudah lewat, sedang dipelajari, akan dipelajari ataupun poster afirmasi sebagai dialog internal. Selain itu juga kombinasi warna-warni dapat memperkuat pengajaran dan belajar siswa, sehingga dapat meransang minat siswa untuk belajar.

2). Penggunaan alat bantu seperti media atau alat peraga; tidak hanya membantu bagi pembelajaran visual, tetapi dapat membantu bagi modalitas pembelajar kinestetik. Siswa yang kinestetik dapat memegang alat bantu, dan mendapatkan sensasi yang lebih baik dari ide yang disampaikan guru. Contoh penggunaan media pada saat pembelajaran biologi yakni dengan menunjukan tumbuhan di dalam kelas dapat memberikan suasana tersendiri bagi siswa. Tumbuhan selain sebagai sumber oksigen, juga dapat sebagai objek pandang yang menarik dan menyejukan pikiran Tumbuhan memberikan efek visual yang indah, sehingga dapat menambah estetika kelas.

3). Pengaturan bangku; susunan bangku dapat mendukung tujuan belajar bagi pelajaran apapun yang diberikan. Susunan bangku dapat memudahkan interaksi sosial, baik antar siswa dengan siswa, siswa dengan guru, siswa dengan sumber belajar lainnya. Dengan demikian, susunan bangku dapat membantu siswa agar tetap fokus pada aktivitas belajar.

4). Penggunaan musik; penggunaan musik dapat menata suasana hati, mengubah keadaan mental siswa, dan mendukung lingkungan belajar yang positif. Musik membantu siswa bekerja lebih baik dan mengingat lebih banyak. Secara sadar maupun tidak sadar, musik dapat merangsang, meremajakan, dan memperkuat belajar. Irama, ketukan, dan keharmonisan musik mempengaruhi fisiologi manusia terutama gelombang otak dan detak jantung, disamping dapat membangkitkan perasaan dan ingatan.

\section{KESIMPULAN}

Proses belajar mengajar pada dasarnya merupakan satu bentuk komunikasi yang terjalin antara komunikator dalam hal ini pengajar yang menyalurkan pesan berupa materi pengajaran kepada komunikan yaitu pelajar .Kemampuan/keterampilan guru dalam melakukan kegiatan komunikasi akan mempengaruhi proses yang akhirnya berujung pada hasil. Untuk menjalin komunikasi yang efektif antara pengajar dan pelajar tergantung dari Metode dan model yang dipakai guru dalam mengajar.

Quantum Teaching menciptakan lingkungan belajar yang efektif, dengan cara menggunakan unsur yang ada pada siswa dan lingkungan belajarnya melalui interaksi yang terjadi di dalam kelas. Quantum Teaching Model TANDUR merupakan kerangkka pengajaran Quatum Teaching dengan langkah-langkah: Tumbuhkan: menumbuhkan minat belajar siswa, Alami: siwa mengalami langsung hal-hal yang dipelajari, Namai: memberikan konsep dan informasi sesuai dengan kebutuhan siswa untuk menjawab keraguan siswa, Demonstrasi: siswa diberi kesempatan untuk berbuat, Ulangi: pengulangan terhadap materi yang dipelajari dan Rayakan: merayakan keberhasilan siswa sebagai bentuk ekspresi keberhasilan siswa.

Penataan lingkungan belajar yang sesuai dengan prinsip-prinsip pembelajaran quantum dapat menselaraskan sistem kerja otak karena meningkatkan kemampuan kognitif siswa melalui kemitraan otak-mata. Dengan lingkungan kelas yang mendukung pada pembelajaran quantum informasi dalam pembelajaran akan tersampaikan jauh lebih komunikatif.

\section{DAFTAR PUSTAKA}

[1] Bratasari R, 2009 Eksperimen Pendekatan Quantum Teaching Dan Quantum Learning Terhadap Pemahaman Konsep Pada Anak Subnormal. Skripsi. Tidak Dipublikasikan. Jurusan Matematika Fakultas Keguruan Dan Ilmu Pendidikan Universitas Muhammadiyah Surakarta

[2] Cahyono, Aris, 2009. Model Pembelajaran TANDUR Berbasis e-Learning Untuk Meningkatkan Aktivitas Siswa Memahami Konsep Hereditas di Kelas XII SMAN Plus Provinsi Riau. Jurnal Inspirasi Pendidikan (Online) http://risecahyono.blogspot.com/2010/01/modelpembelajaran-tandur-berbasis-e.html. diakses tanggal 20 Juni 2010.

[3] Cahyono NA, 2005. Meningkatkan Prestasi Belajar Melalui Pembelajaran Quantum Teaching Bidang Studi IPA Kelas III Di SD Negeri Gunungsari 01 Kecamatan Batangan Kabupaten Pati. Skripsi tidak Dipublikasikan. Semarang: Jurusan Kurikulum dan Tekhnologi Pendidikan Fakultas Ilmu Pendidikan Universitas Negeri Semarang

[4] DePorter, Readon Mark, Nourie S,.2010. Quantum Teaching Memperaktikan Quantum Learning di Ruang Kelas. Bandung: Kaifa 
[5] Hadi, 2009, Membangun Interaksi dan Komunikasi

Dalam Pembelajaran (Online)

http://hadisoen.wordpress.com/2009/11/16/ membangun-interaksi-dan-komunikasi-dalampembelajaran. Diakses tanggl 10 Mei 2010

[6] Given B.K, 2007. Brain-Based Teaching (terjemahan). Bandung: Kaifa

[7] Mahmuddin, 2010, Pengaruh Lingkungan terhadap Efektivitas Pembelajaran (Online)

http://mahmuddin.wordpress.com/2010/02/18/ komunikasi-efektif-antara-guru-dengan-siswa

Diakses tanggl 9 Juni 2010

[8] Miftah M, 2009. Komunikasi Efektif Dalam Pembelajaran. Artikel. (Online)

http://wordpress.com/komunikasi-efektif-dalampembelajaran/. Diakses tanggal 14 Mei 2010.

[9] Rohani, Ahmad, 2008. Pengelolaan Pengajaran. Jakarta: Penerbit Rineka Cipta

[10]Sutirman, 2009. Komunikasi Efektif Dalam Pembelajaran. Artikel. (Online)

http://tirman.wordpress.com/komunikasi-efektifdalam-pembelajaran/.

Diakses tanggal 15 Juni, 2010

[11]Sudrajat, Akhmad, 2009.Beda Strategi, Model, Pendekatan, Metode, dan Teknik Pembelajaran. Makalah Pendidikan..(Online)

http://smacepiring.wordpress.com.

Di akses tanggal 20 Juni 2010

[12]Walujo DA, 2009. Quantum Learning-Quantum Teaching (Online)

http://smacepiring.wordpress.com.

Diakses tanggal 5 Mei 2010 